\title{
Microtubule cytoskeleton perturbation induced by taxol and colchicine affects chaperonin containing TCP-1 (CCT) subunit gene expression in Tetrahymena cells ${ }^{1}$
}

\author{
Cristina Casalou a, Luisa Cyrne ${ }^{\mathrm{a}, \mathrm{b}}$, Mónica Roxo Rosa ${ }^{\mathrm{a}}$, Helena Soares ${ }^{\mathrm{a}, \mathrm{c}, *}$ \\ a Instituto Gulbenkian de Ciência, Apartado 14, P-2781 Oeiras codex, Portugal \\ b Depart. de Quimica e Bioquimica, Faculdade de Ciências, Universidade de Lisboa, Lisboa, Portugal \\ c Escola Superior de Tecnologia da Saúde de Lisboa, Lisboa, Portugal
}

Received 18 June 2001; accepted 15 August 2001

\begin{abstract}
We report the existence of a CCT $\varepsilon$ subunit gene that encodes subunit $\varepsilon$ of the chaperonin CCT (chaperonin containing TCP-1) in Tetrahymena pyriformis. This work focuses on the study of the effects of the microtubule polymerizing agent taxol and the depolymerizing agent colchicine on microtubule dynamics and their role in the regulation of tubulin and CCT subunit genes. Under taxol treatment some TpCCT and tubulin genes are distinctly expressed until $30 \mathrm{~min}$ of treatment. Cytoplasmic TpCCT mRNA levels slightly decrease while tubulin transcripts are increasing. In colchicine treated cells TpCCT and tubulin transcripts decrease in the initial 30 min of treatment and then start to increase. However, both antimitotic agents induce TpCCT and tubulin gene transcription. This induction does not correlate with increased steady-state levels of TpCCT proteins and seems to be necessary to replete cytoplasmic TpCCT mRNAs. Moreover, we found that $\mathrm{TpCCT \varepsilon}$ and $\mathrm{TpCCT} \alpha$ but not $\mathrm{TpCCT} \eta$ are present in the insoluble fraction after a postmitochondrial fractionation that contains components of the ciliate cortex structure, basal bodies and cilia. This suggests that some TpCCT subunits may be associated with these structures. The association of TpCCT $\varepsilon$ subunit is stimulated either by taxol or colchicine treatment. These observations support the idea that CCT subunits could have additional roles in vivo. (C) 2001 Elsevier Science B.V. All rights reserved.
\end{abstract}

Keywords: Chaperonin CCT; Microtubule; Taxol; Colchicine; Tetrahymena

\section{Introduction}

Chaperonins are a class of molecular chaperones comprised of large multisubunit assemblies essential in mediating the folding of newly synthesized polypeptides in an ATP-dependent manner. Two families of chaperonins have been identified: class I comprising GroEL in eubacteria, Hsp60 in mitochondria and Rubisco binding protein in chloroplasts; class II, comprising the thermosome, TF55 in archaebacteria and the eukaryotic cytosolic chaperonin containing TCP-1 (CCT). CCT differs from GroEL both in architecture and in function. It exists as a hetero-

* Corresponding author, at address a. Fax: +351-21-440-7970.

E-mail address: msoares@igc.gulbenkian.pt (H. Soares).

${ }^{1}$ GenBank accession No.: Banklt 356185 AF303531. oligomeric complex of about $850-900 \mathrm{kDa}$ containing eight different, but related gene products (for review [1]). In yeast, all CCT subunit genes are essential without any redundancy among them, i.e. overexpression of one cannot rescue the lethality of the null allele of another. This suggests that each CCT subunit has a distinct function conferring a specific property to the chaperonin and/or is required to assemble the whole complex. Indeed, actin binds to $\mathrm{CCT}$ by specific interactions with subunits СCT $\delta$ and СCT $\beta$ or with CCTE [2]. By genetic analysis Lin and Sherman [3] have proposed that there is a unique hetero-oligomeric arrangement of the yeast CCT subunits. In metazoan, the CCT $\alpha / \mathrm{TCP}-1$ gene is highly expressed in testis [4], embryos in early stages and rapidly growing cells in tissue culture [5]. CCT mRNA expression is strongly up-regulated during cell growth especially from $\mathrm{G}_{1} / \mathrm{S}$ transition to early $S$ phase [6], implicating them in cell cycle regulated events probably by assisting the folding of tubulin and/or other proteins. Recently, it was shown that CCT subunit levels are up-regulated in several mammalian 
cell lines during recovery from chemical stress [7], suggesting that they respond to protein damage and play a role in recovery of cells under stress.

In vivo CCT plays an important role in the folding of newly translated tubulins ( $\alpha-, \beta$ - and $\gamma$-tubulin), actin (for review see [1]) and is intimately connected with the formation of microtubules (Mts) [8-10]. In contrast with actin the productive folding of $\alpha$ - and $\beta$-tubulin in vivo requires, in addition to CCT, the presence of GTP and a set of protein co-factors $[11,12]$, which act on the polypeptides after the release of tubulin from CCT. The levels of these proteins appear to affect the dynamics of Mts in vivo. It has been proposed that some of these factors play an important role during the quality control in the assembly of tubulin heterodimer by activating certain GTPases [13]. In addition to the $900 \mathrm{kDa}$ cytosolic complex, free subunits of CCT or smaller oligomeric structures consisting of subsets of CCT subunits have been detected in various different cell types [14-17]. It has been suggested that these micro-complexes may be intermediates in the assembly of the intact CCT [14]. However, there is evidence that free CCT subunits can play additional roles in cells. The TCP-1/CCT $\alpha$ has been detected in centrosomes and incubation of these structures in vitro with an antibody to $\mathrm{CCT} \alpha / \mathrm{TCP}-1$ prevents $\mathrm{Mt}$ growth, indicating that CCT $\alpha / \mathrm{TCP}-1$ may assist in Mt nucleation [18]. More recently, Roobol et al. [19] showed that CCT subunits $\alpha, \gamma$, $\zeta$ and $\theta$ associate with assembled Mts in vitro behaving as typical Mt associated proteins. The CCT $\theta$ subunit has also been implicated with the Ras signaling pathway during yeast morphogenesis [20].

Tetrahymena is a protozoan ciliate with a variety of distinct Mt structures displaying functional diversity and dynamics. This ciliate possesses a CCT gene family homologous to the mouse CCTs. We have previously done the molecular characterization of four members of this gene family, namely TpCCT $\alpha$, ТрCCT $\gamma$, TpCCT $\eta$ and TpCCT $\theta$ [21-24] and shown that CCT subunit genes are up-regulated during active cell division and ciliary assembly which suggests the involvement of these CCT subunits in these processes. Here we report the isolation and characterization of the TpCCTE subunit gene from Tetrahymena. Mts are the targets for a large number of antimitotic agents including taxol and colchicine. These agents able to suppress $\mathrm{Mt}$ dynamics are useful probes to investigate the role of these polymers in vivo. We investigated the possible effects of taxol and colchicine in the Mt cytoskeleton using a confocal laser microscope and a monoclonal antibody against $\alpha$-tubulin. This allowed us to establish the effects of taxol and colchicine on the Mt cytoskeleton of Tetrahymena. Under these conditions we have observed that tubulin and CCT subunit gene expression is affected. Moreover, CCT $\alpha$ and CCT $\varepsilon$ subunits but not CCT $\eta$ are unexpectedly associated with insoluble fractions after postmitochondrial fractionation and the association of CCTE subunit is stimulated either by taxol or colchicine treat- ment. The differential association of some CCT subunits with the insoluble fractions that contain the ciliate cortex structure, basal bodies and cilia suggests that the different CCT subunits may have distinct roles in cells either when acting as free subunits and/or as part of oligomeric structures.

\section{Material and methods}

\subsection{Cells and culture conditions}

Tetrahymena pyriformis amicronucleated CGL strain was grown axenically in enriched proteose/peptone/yeast extract medium (PPY) at $28^{\circ} \mathrm{C}$ [25]. Cells were harvested in the stationary phase at a density of $1.5 \times 10^{6}$ cells $/ \mathrm{ml}$ for DNA extraction. For RNA and protein extraction, cells were collected in the exponential phase at $2 \times 10^{5}$ cells $/ \mathrm{ml}$. Taxol (50 $\mu \mathrm{m}$, paclitaxel Sigma) [26] or colchicine (10 mM, Sigma) [27] were added in exponential phase. In the presence of the antimitotic agents the cells were swimming and alive for more than $6 \mathrm{~h}$ as revealed by optical microscopic observations; however, the shape of the cell was altered since $30 \mathrm{~min}$ of treatment.

\subsection{Cloning of TpCCTE gene}

Degenerated primers (primer 1 5'-GCCTCTAGAAAYGAYGGTGCYACYATY-3' and primer 2 5'-TTCGAACCRCCRAAGCCR-3') were used to amplify $T$. pyriformis genomic DNA using PCR cycling conditions as previously described [22]. The PCR product $(\sim 1.0 \mathrm{~kb}$ fragment for $T$. pyriformis) was cloned into pUC19 plasmid and sequenced. One of the clones, named PCRE24, contains the $T$. pyriformis $1.0 \mathrm{~kb}$ amplified fragment, which encodes a predicted amino acid sequence related to the mouse CCTE [28]. This fragment was used to screen a Sau3AI genomic library [21]. Filters were prehybridized and hybridized using the conditions described in Cyrne et al. [22], except that the hybridization and washing temperature was $42^{\circ} \mathrm{C}$. One of the positive clones, named TpCCTE6.1.1, was analyzed by restriction mapping. Restriction fragments were subcloned in pUC19 plasmid. Sequencing and sequence analysis were performed as referred in [22].

\subsection{Northern blot hybridization}

Total cytoplasmic RNAs from $T$. pyriformis exponentially growing cells and cells treated with taxol or colchicine at different times were extracted and analyzed by Northern blot as described by Sambrook et al. [29]. When hybridizations were performed using $\beta$ TT1 as probe [30], the conditions were the same as described by Soares et al. [26]. Hybridizations carried out using probes from T. pyriformis TpCCT subunit genes were essentially per- 
formed as described by Soares et al. [26]. When hsp70 [26] and actin oligonucleotide (5'-CTCTGGGAGCATCGTCACCAGC-3') [31] probes were used, hybridization conditions were those described in [32]. Hybridizations using TU20 gene as probe were done essentially as described by Neves et al. [33].

\subsection{Radioactive probes}

T. pyriformis TpCCTE gene DNA probe was prepared from pTpe6H1 plasmid DNA hydrolyzed with SphI to generate $\mathrm{a} \sim 4 \mathrm{~kb}$ fragment that contains the coding region of this gene. The homologous DNA probe encoding T. pyriformis TpCCT $\alpha$ subunit was prepared from $\mathrm{pT} 7$ plasmid [24], ТрССТ $\eta$ was prepared from $\mathrm{pT} \mathrm{pH} 2.3$ plasmid [22], whereas TpCCT $\gamma$ subunit and $\beta$ TT1 tubulin were prepared from pTpE3 and IB1 plasmid, respectively, as described in [21]. The ubiquitin probe was prepared from pTU20 plasmid [33]. Fragments were labeled using the Megaprime DNA labeling system (Amersham) and $[\alpha-$ $\left.{ }^{32} \mathrm{P}\right] \mathrm{dATP}(3000 \mathrm{Ci} / \mathrm{mmol})$ (Amersham International plc). The hsp70-specific oligomer and actin oligomer were synthesized with the gene Assembler system (Pharmacia LKB Biotechnology) and labeled using $\left[\gamma^{32}\right.$ P]ATP $(3000 \mathrm{Ci} /$ mmol) (Amersham International plc.) as described by Soares et al. [32].

\subsection{Run-on transcription assays}

T. pyriformis nucleus isolation and run-on transcription assays were performed essentially as described by Soares et al. [26] using $5 \times 10^{8}$ nuclei. The average incorporation per assay was about $10^{7} \mathrm{cpm}$. One microgram of the following purified fragments was dotted into nitrocellulose filters: $\alpha$ tubulin $-8 \mathrm{~kb}$ HindIII fragment from IB $\alpha$ [30]; $\beta$-tubulin $-3 \mathrm{~kb}$ HindIII fragment from IB1 [30]; TpCCT $\alpha-\sim 2.9$ $\mathrm{kb}$ EcoRI fragment from TpCCT $\alpha 1.1$ [23]; TpCCTE -

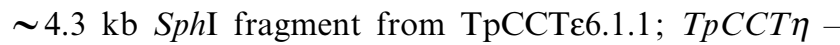
$\sim 2.3 \mathrm{~kb}$ HindIII fragment from TpCCT 11.3 [22]; TpCCT $\gamma-\sim 2.2 \mathrm{~kb}$ EcoRI fragment from pTpE3 [21]; ubiquitin $-\sim 1.0 \mathrm{~kb}$ HindIII fragment from pTU20 [33].

\subsection{Digitalization of autoradiograms}

The autoradiograms have been digitally generated and processed after being scanned (Epson GT12000) using as software Paint Shop Pro version 4.15 and Microsoft Power Point 2000.

\subsection{Production of polyclonal antibodies}

A peptide from the $\mathrm{N}$-terminal region of TpCCTE (see Fig. 1) was synthesized and cross-linked to PPD (purified protein derivative of Mycobacterium tuberculosis). This conjugated peptide mixed with equal volumes of Freund's complete or incomplete adjuvant was injected three times into rats $(50 \mu \mathrm{g}$ of TpCCTE peptide) at 2 week intervals.

\subsection{Preparation of protein extracts from Tetrahymena cells}

To obtain total protein extracts, Tetrahymena exponentially growing cells $\left(3 \times 10^{5}\right.$ cells $)$, cells treated with taxol and colchicine for different times were pelleted at $3000 \times g$ for $5 \mathrm{~min}$ at $4^{\circ} \mathrm{C}$ and washed in ice-cold buffer A $(50 \mathrm{mM}$ HEPES-KOH, pH 7.6, $2 \mathrm{mM}$ EDTA, $100 \mathrm{mM} \mathrm{NaCl}$ and $250 \mathrm{mM}$ sucrose). They were then resuspended in buffer $\mathrm{B}$ (50 mM Tris- $\mathrm{HCl}$ pH 6.8, 7.5\% (v/v) 2-mercaptoethanol, $1.5 \%(\mathrm{w} / \mathrm{v}) \mathrm{SDS}$ and $0.75 \mathrm{mM}$ PMSF) and boiled for $3 \mathrm{~min}$.

Postmitochondrial extracts of Tetrahymena exponentially growing cells $\left(3 \times 10^{5}\right.$ cells $)$, cells treated with taxol or colchicine were prepared according to [23]. The soluble fraction corresponding to the postmitochondrial extract was separated from the pellet designated as insoluble fraction. The pellet was resuspended in buffer $B$ and boiled for $3 \mathrm{~min}$. For the preparation of each sample the same number of cells was used and the total amount of protein obtained was loaded in SDS-PAGE.

\subsection{SDS-PAGE and Western blot analysis}

SDS-PAGE was carried out according to [23]. Immunodetection was performed as described in [23]. The dilutions of the polyclonal antibodies against TpCCT subunits and of the mouse monoclonal antibody against to $\alpha$-tubulin N356 purchased from Amersham are indicated in the legends of the figures.

\subsection{Indirect immunofluorescence}

For immunofluorescence staining $T$. pyriformis cells were grown until exponential phase. After treatment with taxol or colchicine for different times cells were washed with PHEM solution (60 mM PIPES, $25 \mathrm{mM}$ HEPES, $10 \mathrm{mM}$ EGTA, $2 \mathrm{mM} \mathrm{MgCl}_{2}$; $\mathrm{pH}$ 6.9) followed by permeabilization with $0.15 \%$ (v/v) Triton X-100 in PHEM for $5 \mathrm{~min}$ at room temperature. The permeabilized cells were then fixed for 30 min with $2 \%(\mathrm{v} / \mathrm{v})$ paraformaldehyde in PHEM and the monoclonal antibody anti- $\alpha$ tubulin (Amersham Pharmacia, N356) was used as the primary antibody (1/100 dilution) in buffer $\mathrm{C}(0.1 \%(\mathrm{v} / \mathrm{v})$ Tween 20, 2\% (w/v) BSA in PBS) during $1 \mathrm{~h}$. Cells were washed in buffer $\mathrm{C}$ and incubated with the secondary antibody (fluorescein-conjugated goat anti-mouse; Jackson ImmunoResearch Laboratories) diluted 1/200 for $1 \mathrm{~h}$. After washing in buffer C, DNA was stained with DAPI $(0.5 \mu \mathrm{g} / \mathrm{ml}$; Sigma, D9542) and cells were mounted in a VectaShield mounting medium (Vector Laboratories). Confocal microscopy was performed according to [34]. 
1

TpCCTE

ScCCTE

СасCTE

AsCCTE1

AsCCTE2

MmCCTE

HsCCTE

Consensus

TрCCTE

ScCCTE

СaCCTE

AsCCTE1

AsCCT\&2

MmCCTE

HsCCTE

Consensus

TpCCTE

SCCCTE

CaCCTE

AsCCT\&1

AsCCTE2

MmCCTE

HsCCT $\varepsilon$

Consensus

TрCCTE

ScCCTE

CaCCTE

AsCCTE1

AsCCTE2

MmCCTE

HsCCTE

Consensus

TpCCT 8

ScCCT 8

СаCCT $\varepsilon$

AsCCTE1

AsCCT\&2

MmCCT $\varepsilon$

HsCCT 8

Consensus

TpCCTE

ScCCTE

CaCCTE

AsCCTE1

AsCCTE2

MmCCTE

HsCCTE

Consensus

TpCCTE

ScCCTE

CaCCTE

AsCCTE1

AsCCTE2

MmCCTE

H SCTE

Consensus MSIAA FDEYGRPFII IREODSKKRL KGVDAYKSNI AAAKTIASTL RSSLGPKGMD KMMISPDGEV SV TNDGATIV MPDLSNAIVA QDEMGRPFII VKDQGNKKRQ HGLEAKKSHI LAARSVASII KTSLGPRGLD KILISPDGEI TITNDGATII MAQSSAQLL FDESGQPFIV MREQENQKRI TGVEAVKSHI LAARAVANTL RTSLGPRGLD KMLVSPDGDV TITNDGATM .... MAIA FDEYGRPFII LREQEKKSRL QGLDAHKANI AAAKAIARIL RTSLGPKGMD KMLQSPDGDV TITNDGATHL ..... MALD FDEYWRPFII LREQEKKSRL QGLDAQKANI AAGKSVARIL RTSLGPKGMD KMLQSPDGDV TITNDGATHI .MASVGTLA FDEYGRPFLI IKDQDRKSRL MGLEALKSHI MAAKAVANTM RTSLGPNGLD KMMVDKDGDV TITNDGATIL . MASMGTLA FDEYGRPFLI IKDQDRKSRL MGLEALKSHI MAAKAVANTM RTSLGPNGLD KMMVDKDGDV TVINDGATHL -------- -DE---PF-I --EQ----R- -G-EA-K--I -A---VA--- --SLGP-GLD K-L---DGDV -IITNDGATI-

81

EKMDIQHPVA KLMVELSQSQ DNEITGGTTG VVVFAGALLE QANKLIDKGL HPLKIADGFD KACEIAVARL DEIAEEIDIQ SQMELDNEIA KLLVQLSKSQ DDEIGDGTTG VVV.ASALID QALELIQKGI HPIKIANGFD EAAKLAISKL EETCDDISAS EKMDVQHHVA KIMVELSKSQ DHEIGDGTTG VVVAAGALLE EAEKLIDRGI HPIKIADGFD LACKKALETL DSISDKFPVE ELMDVDNQIA KLLVELSRSQ DYDIGDGTTG VVVIAGALLE QAEKLLERGI HPIRVAEGYE MASRIAVDHL ESISTKYEFS ELMDVDNQIA KLMVELSRSQ DYDIGDGTTG VVVIAGSLLE QABKLLERGI HPIRVABGYE MASRIAVDHL ESISTKYEFS SMMDVDHQIA KIMVELSKSQ DDEIGDGTTG VVV.AGALLE EAEQLIDRGI HPIRIADGYE QAARIAIQHL DKISDKVLVD SMMDVDHQIA KIMVELSKSQ DDEIGDGTTG VVV.AGALLE EAEQLLDRGI HPIRIADGYE QAARVAIEHL DKISDSVLVD --MD----IA KIMV-LS-SQ D-EIGDGTTG VVVFA--LLE -A--L---G- HP--IA-GYE-A---A---L D--------

161 7

ENN. .HERLI EAAMTALSSK VVSKNKRKMA QIAVDAVLSV ADLERRDVNF DLIKLQEKTG GSLEDTRLIQ GILIEKDMSH NDELFRDFLL RAAKTSLGSK IVSKDHDRFA EMAVEAVINV MDKDRKDVDF DLIKMQGRVG GSISDSKLIN GVILDKDFSH ..N. .RERLV ETAQTSLGSK IVNRSLRQFA EIAVDAVLSV ADIESKDVNF EMIKMIEGKVG GRLEDTILVK GIVIDKTMSH ATD. IEPLV QTCMTTLSSK IVSRCKRALA EISVKAVLAV ADLERKDVNL DLIKVEGKVG GKLEDTELVE GIIVDKDMSH ATD. .IEPLV QTCMTTLSSK IVSRCKRALA EIAVKAVLAV ADLERKDVNL DLIKVEGKVG GKLEDTELVQ GIIVDKDMSH INN. .PEPLI QTAKTTLGSK VINSCHRQMA EIAVNAVLTV ADMERRDVDF ELIKVEGKVG GRLEDTKLIK GVIVDKDFSH IKD. .TEPLI QTAKTTLGSK VVNSCHRQMA EIAVNAVLTV ADMERRDVDF ELIKVEGKVG GRLEDTKLIK GVIVDKDFSH $---E-I-~----T-L-S K$ IV-----MA ---V-AV--V -D-E--DV-F DLIK-----G G---D--II- GI--DK--SH $241 \quad$ PQMVKEV. . . . . KDAKTAI LTCPFEPPKP KTKHNINISS AEDYKKLYQQ EQQYFREMVD DCKKSGANII MCQWGFDDEA PQMPKCVLPK EGSDGVKLAI LTCPFEPPKP KTKHKLDISS VEEYQKLQTY EQDKFKKMID DVKKAGADVV ICQWGFDDEA PQMPKEL... . . KNAKVAI LTCPFEPPKP KTKHKIDITS TEDFKALRDY ERETFETMIR QVKESGATLA ICQWGFDDEA PQMPKRI... . . YDAHIAI LTCPFEPPKP KTKHKVDIDT VEKFQTLRGQ EQKYFDEMVQ KCKDVGATLV ICQWGFDDEA PQMPKRI. . . . .EDAHIAI LTCPFEPPKP KTKHKVDIDT VEKFQTLRGQ EQKYFDEMVQ KCKDVGATLV ICQWGFDDEA PQMPKKV. . . . . VDAKIAI ITCPFEPPKP KTKHKLDVMS VEDYKALQKY EKEKFEEMIK QIKETGANLA ICQWGFDDEA PQMPKKV. . . . . EDAKIAI LTCPFEPPKP KTKHKIDVTS VEDYKALQKY EKRKFEEMIQ QIKETGANLA ICQWGFDDEA PQM-K--- - -

321

NHLLLQADLP AVRWVSGTDI ELIAVATGGR IVPRFEELSN DKLGEAKLVR EIQFGTSNER MLVIEDCKQS KAVTILIRGG NHLLLQNDLP AVRWVGGQEL EHIAISTNGR IVPRFQDLSK DKLGTCSRIY EQEFGTTKDR MLIIEQSKET KTVTCFVRGS NHLLQANDLP AVRWVGGPEI ELLAIATNAR IVPRFSELSK EKLGTAGLVR EITFGAAKDR MLSIEQCPNN KAVTIFVRGG NHLIMQRELP AVRWVGGVEL ELIAIATGGR IVPRFQELST EKLGKAGLVR EKSFGTTKDR MLYIEKCANS KAVTIFIRGG NHLIMQRELP AVRWVGGVEL ELIAIATGGR IVPRFQELST EKLGKAGLVR EKSFGTTKDR MIYIEKCANS KAVTIFIRGG NHLLLQNGLP AVRWVGGPEI ELIAIATGGR IVPRFSELTS EKLGFAGVVQ EISFGTTKDK MLVIEKCKNS RAVTIFIRGG NHLLLQNNLP AVRWVGGPEI ELIAIATGGR IVPRFSELTA EKLGFAGLVQ EISFGTTKDK MLVIEQCKNS RAVTIFIRGG NHLL---IP AVRWV-G-E- E--AI-T--R IVPRF-EL-- EKLG----V- E--FG---D- ML-IE----- --VT-FIRG-

401

480 SNMIVSEARR SIHDANCVIR NLIKCPY IVY GGGSAEIACS LTVNQEADKI SSVEQYAVRA FADALEDIPN ALADNSGLNP NKMIVDEAER ALHDSLCVVR NLVKDSFVVY GGCAAEVTMS LAVSEEADKQ RGIDQYAFRG FAQALDTIPM TLAENSGLDP NKMI IDEAKR ALHDALCVIR NLVRDSF IVY GGCSAELAAA IQVAKEADRI DGIEQYAFRA FADALESIPM ALAENSGLAP NKMMIEETKR SIHDALCVAR NLIINNSIVY GGCSAEISCS IAVEAAADRH PGVEQYAIRA FADALDAIPL ALAENSGLPP NKMMIEETKR SIHDALCVAR NLIINNSIVY GGCSAEISCS IAVEAAADRH PGVEQYAIRA FADALDAIPL ALAENSGLPP NKMIIEEAKR SLHDALCVIR NLIRDNFVVY GGCAAEISCA LAVSQEADKC PTLEQYAMRA FADALEVIPM ALSENSGMNP NKMI IEEAKR SLHDALCVIR NLIRDNFVVY GGCAAEISCA ILAVSQEADKC PTLEQYAMRA FADALEVIPM ALSENSGMNP $--M-I-E--R$--HD--CV-R NLI--- IVY GGS-AE---- --V---AD-- ---EQYA-R- FA-ALE-IP- -L-ENSGL-P

481 7553 IEAVANAKAL QNSQTNPRIG VDCQLEGTFD MREQKVYETY LSKKQQFQLA TQVVKMILKI DDVIAPEQ*.. ... IGTLSTLKSK QLKRKISNIG VDCLGYGSND MKELFVVDPF IGKKQQILLA TQLCRMILKI DNVIISGKDE Y*.. IDALSDLKAK QIETGKSSLG IDAVFAGTND MREQKVIETL LSKREQISLA TQVVRMILKI DDVRVPDDER MGY* IDTLTVVKSQ HVKENNSRCG IDCNDVGTND MKEQNVFETL IGKQQQILIA TQVVKMILKI DDVITPSEY* .... IDTLTVVKSQ HVKRNNSRCG IDCNDVGTND MKEQNVFETL IGKQQQILLA TQVVKMILKI DDVITPSEY* .... IQTMTEVRAR QVKESNPALG IDCLHKGSND MQYQHVIETL IGKKQQISLA TQMVRMILKI DDIRKPGESE E*. . IQTMTEVRAR QVKEMNPALG IDCLHKGTND MKQQHVIETL IGKKQQISLA TQMVRMILKI DDIRKPGESE E*.. I------- --- - G ID----G--D M----V-E-L --K--Q--LA TQ---MILKI D-V----- --. 
Fig. 1. Alignment and comparison of Tetrahymena CCTE deduced amino acid sequence with those from different organisms. The deduced amino acid sequence for the T. pyriformis CCTE polypeptide was aligned and compared with those from other organisms (accession numbers from the EMBL data base are indicated): Saccharomyces cerevisiae (P40413); C. elegans (P47209); A. sativum (AS1-P40412; AS2-P54411); Mus musculus (P80316) and Homo sapiens (P48643). Gaps were inserted when required to maximize the alignment and are represented by points. Asterisks indicate the end of the open reading frames. Arrows indicate the intron positions of the $T$. pyriformis gene. The conserved sequences between almost all chaperonins, including the traditional chaperonins, are indicated by open boxes. The conserved sequences shared only by CCTE subunits are shadowed. The sequence peptide used to elicit the polyclonal antibody against TpCCTE subunit is underlined.

$\leftarrow$

\section{Results}

\subsection{The TpCCTE subunit gene, predicted amino acid sequence and the specific antibody against this subunit}

Using degenerate primers we amplified by PCR a $1.0 \mathrm{~kb}$ genomic DNA fragment and determined the partial sequence of this fragment. A database search of the sequence of this fragment revealed that the amplified fragment encodes a polypeptide highly similar to the mouse $C C T \varepsilon$ subunit [28]. This fragment was used as a probe to screen a $T$. pyriformis genomic library constructed in $\lambda$-Dash II [21]. One of the positive clones, designated TpCCTE6.1.1, contained the complete sequence of the $T p C C T \varepsilon$ subunit gene as determined by sequence analysis. Analogous to other Tetrahymena TpCCT subunit genes the coding region of the $T p C C T \varepsilon$ gene is also interrupted by six introns (see Fig. 1 for the intron positions).

The protein encoded by the TpCCTE gene consists of 534 amino acid residues and possesses a predicted molecular mass of $58.9 \mathrm{kDa}$ and a putative $\mathrm{p} I$ of 5.1 . A comparative analysis of the putative $\mathrm{p} I$ of this Tetrahymena CCT subunit with the $\mathrm{pI}$ of the other known subunits shows that this subunit is probably the most acidic CCT subunit of Tetrahymena. Similarly to other TpCCT subunits, the predicted amino acid sequence of TpCCTE on comparison with other CCTE subunits from different organisms exhibits a high degree of sequence similarity, ranging from 80\% with Caenorhabditis elegans (P47209) to $79.2 \%$ with mouse [28]. The degree of similarity decreases when this comparison is extended to the other Tetrahymena CCT subunits (namely $51.4 \%$ for TpCCT $\theta$ to $59.2 \%$ for $\mathrm{TpCCT} \delta$ ). The predicted amino acid sequence of Tetrahymena TpCCT $\varepsilon$ when aligned with the other known CCTE subunits from other organisms shown in Fig. 1 reveals that TpCCTE also contains the sequence motifs that are conserved in almost all group I chaperonins and in members of the CCT/TF55 protein family (for review see [1]). These include the motifs TNDGATIL that in TpCCTE is apparent as TNDGATIV (positions 67-73), GDGTTSV, which is conserved among all CCT but extended as -IGDGTTGVVV- (positions 98-107), and $\mathrm{V}(\mathrm{P} / \mathrm{A}) \mathrm{GGG}$ in the form of VYGGG (positions 419423). Interestingly, five highly conserved regions, AILTCPFEPPKPKTKH (positions 245-260), CQWGFDDEANHLL (positions 298-310), LPAVRWV (positions 315-321), RIVPRF (positions 236-241) and MILKID (po- sitions 522-527), seem to be exclusively common to CCTE subunits.

From the predicted amino acid sequence of TpCCTE we synthesized a peptide of the N-terminal region of the protein and produced a polyclonal antibody specific to the Tetrahymena $\mathrm{CCT} \varepsilon$ subunit. As can be seen from Fig. 2 the TpeNterm antibody specifically reacts with a protein of $60 \mathrm{kDa}$ present in Tetrahymena postmitochondrial extracts, whereas no reactivity is observed with preimmune serum. The reactivity was totally eliminated when the serum was preincubated with an excess (500-700 $\mu \mathrm{g})$ of the synthetic peptide used to produce the antibodies. These results clearly show that this antibody specifically recognizes the Tetrahymena CCTE subunit.

\subsection{Taxol and colchicine effects on Mt arrays of Tetrahymena cells}

We investigated the effects of taxol and colchicine on the morphological and subcellular status of the Tetrahymena Mts using a confocal laser microscope and a monoclonal antibody against $\alpha$-tubulin (see Section 2 ). We observed in detail the intracellular Mts of exponentially

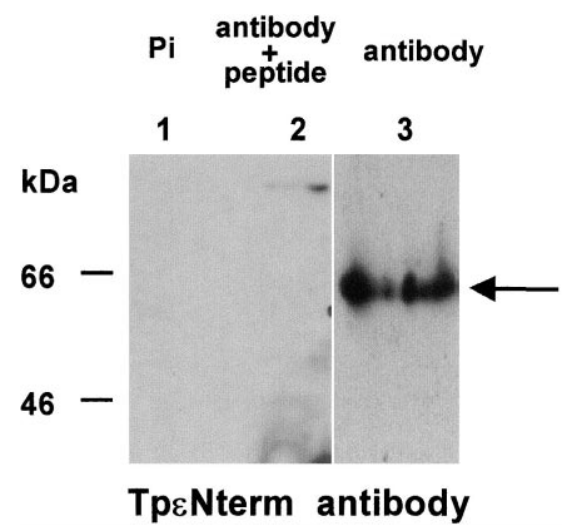

Fig. 2. Characterization of the polyclonal antibody produced against Tetrahymena CCTE subunit. The peptide of the N-terminal region of the predicted amino acid sequence of the TpCCTE subunit was synthesized, conjugated with the carrier protein PPD and injected into rats to produce polyclonal serum. The Tetrahymena preimmune and polyclonal serum was analyzed using postmitochondrial extracts $(20 \mu \mathrm{g})$ resolved by $10 \%$ SDS-polyacrylamide gels and Western blotting. Lanes: 1, incubation with the preimmune serum; 2, incubation with the polyclonal antibody pre-absorbed with synthetic peptide $(700 \mu \mathrm{g}) ; 3$, incubation with the respective polyclonal antibody. The primary antibody as well as the secondary antibody were used in all the cases in a dilution of 1/750. Molecular mass markers are indicated on the left. 

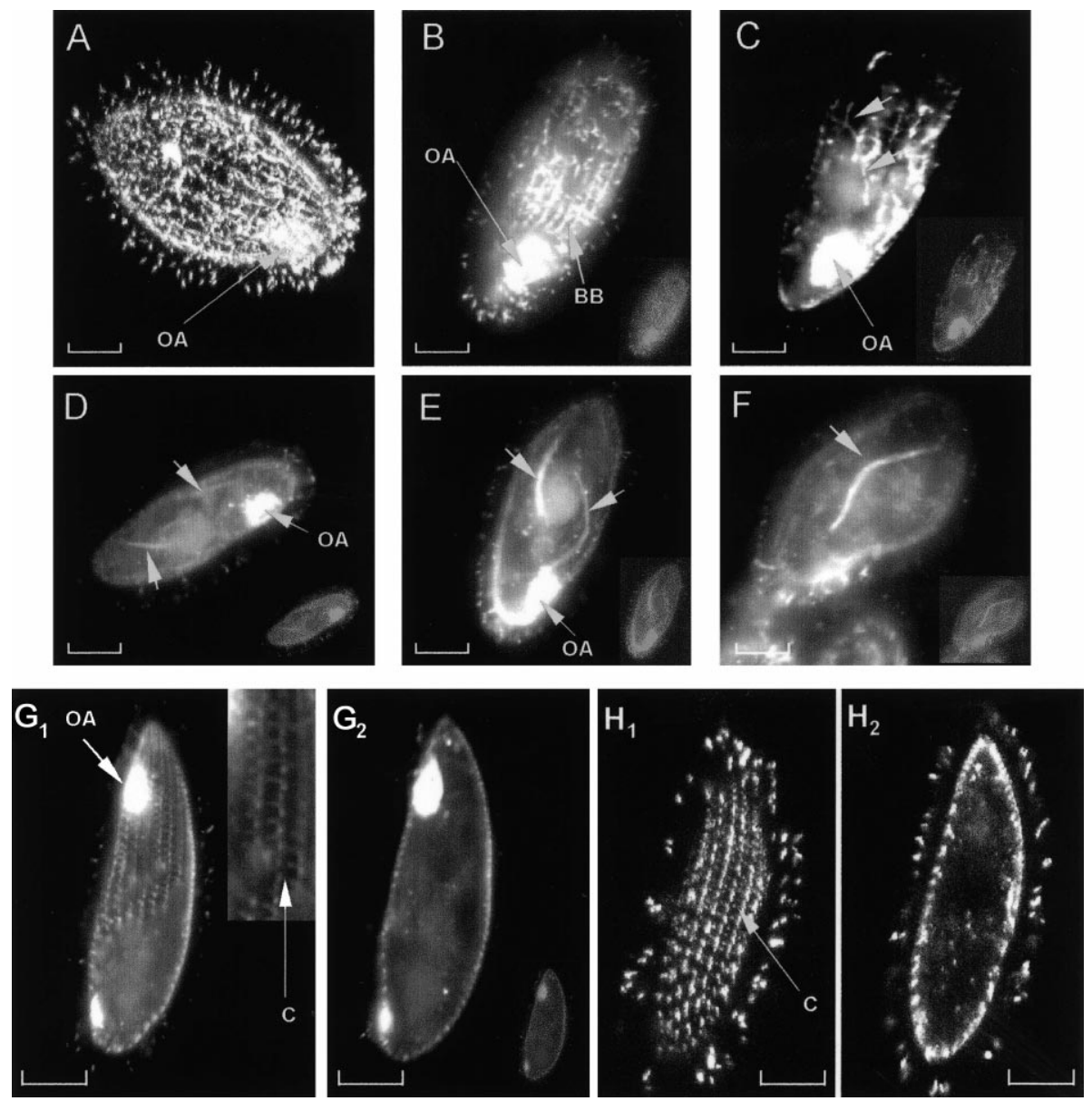

Fig. 3. Immunofluorescence analysis of Tetrahymena exponentially growing cells and cells treated with taxol and colchicine using a monoclonal antibody against $\alpha$-tubulin. Localization of tubulin was performed in exponentially growing cells (A-C), cells treated with taxol for 90 min (D-F) and colchicine for $90 \mathrm{~min}\left(\mathrm{G}_{1}, \mathrm{G}_{2}, \mathrm{H}_{1}, \mathrm{H}_{2}\right)$, permeabilized with $0.15 \%$ (v/v) Triton X-100, fixed in $2 \%$ (v/v) paraformaldehyde and labeled with a monoclonal anti- $\alpha$-tubulin (Amersham) (detected with fluorescein (FITC)). (A) The exponentially growing cell surface was focused on; several longitudinal rows of intact cilia are visible; the tips of cilia are preferentially labeled; the oral apparatus (OA) is also observable. (B) Using a confocal laser scanning microscope this picture was taken immediately under the surface of an exponentially growing cell; longitudinal rows of cilia are still visible; basal bodies (BB) are also decorated by the antibody (arrow); OA is strongly labeled; macronucleus stained with DAPI is starting to be visible (see small picture in the low right corner). (C) This picture was taken at the macronucleus plane as shown by DAPI staining; very thin Mts are observable surrounding the macronucleus (arrows). (D-F) Confocal optical sections at the macronucleus plane of distinct taxol treated cells for 90 min; note the visible bundles of Mts surrounding the macronucleus that were absent in exponentially growing cells (see arrows). $\left(\mathrm{G}_{1}, \mathrm{H}_{1}\right)$ Confocal optical sections at the surface of two cells treated with colchicine for $90 \mathrm{~min}$; note the disappearance of Mt arrays at the cortex level. In the upper right corner of $\mathrm{H}_{1}$ a clear detail of the infraciliature is shown, suggesting that microtubular systems have been depolymerized. $\left(\mathrm{G}_{2}, \mathrm{H}_{2}\right)$ Pictures at the macronucleus plane of two cells treated with colchicine for $90 \mathrm{~min}$. The internal Mt networks are no longer visible. Bar $=14 \mu \mathrm{m}$.

growing cells and cells subjected to taxol and colchicine (Fig. 3). In control cells when the focus is on the cell surface, the $\alpha$-tubulin antibody decorates the basal bodies (BB) that are arranged in longitudinal arrays with the oral apparatus (OA) and intact cilia are clearly visible; we must state that the tip of the cilia is preferentially labeled (Fig. 3A,B). Thin Mt filaments are frequently detectable under the cortex (see Fig. 3C, see arrows). At the nuclear level the images show a number of Mt surrounding the macronucleus (see Fig. 3C, see arrows). In cells treated with taxol the intracellular Mt arrays were replaced by bundles of Mts that are preferentially located around the macronucleus (see Fig. 3D-F). These bundles apparently result from the massive polymerization of Mts induced by the drug. In cells treated with colchicine, we observed the disappearance of Mt arrays at the cortex level (Fig. $3 \mathrm{G}_{1}, \mathrm{H}_{1}$ ). In Fig. $3 \mathrm{G}_{1}$ a clear detail of the infraciliature is shown, suggesting that microtubular systems have been depolymerized by the action of colchicine. Additionally, the internal Mt networks are no longer visible, which indicates that they have also been affected by the colchicine treatment (see Fig. $3 \mathrm{G}_{2}, \mathrm{H}_{2}$ ). These data clearly show that taxol and colchicine affect the Tetrahymena cortex structure and Mt cytoskeleton organization.

\subsection{Expression of CCT, tubulin and actin genes in Tetrahymena cells treated with the depolymerizing and polymerizing agents colchicine and taxol}

Taxol and colchicine have been shown to regulate gene 
expression in eukaryotic cells $[27,35,36]$. Since taxol and colchicine cause alterations in the Tetrahymena Mt cytoskeleton we have investigated the effects of this cytoskeleton perturbations on CCT, tubulin and actin gene expression by Northern blot analysis (Fig. 4). Using total cytoplasmic RNA prepared from exponentially growing cells and cells treated with colchicine for different times we found that the amount of the steady-state population of the $T p C C T \alpha, T p C C T \varepsilon, T p C C T \gamma$ and $T p C C T \eta$ subunit mRNAs and the $\beta$-tubulin mRNA ( $\beta T T 1)$ decreases until 30 min of colchicine treatment when compared to control cells (Fig. 4). Afterwards one sees that the levels of these steady-state populations of mRNAs start to increase. At

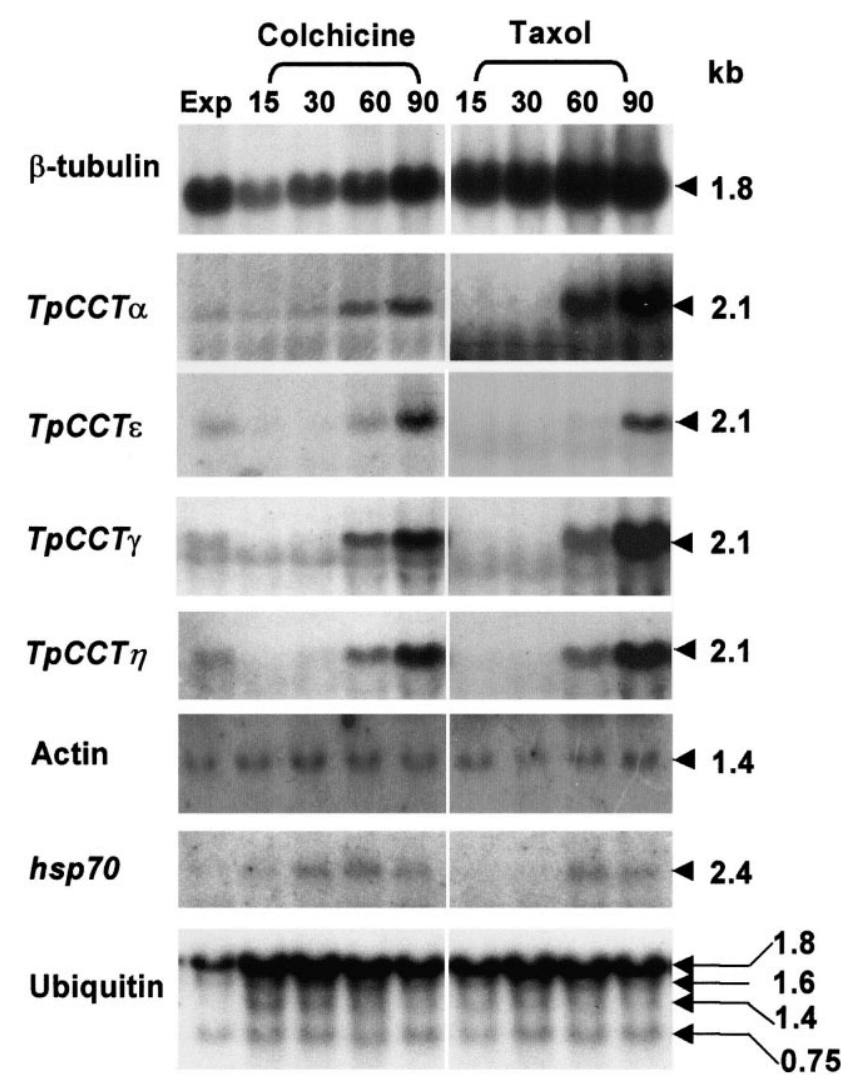

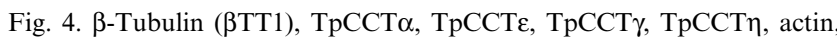
hsp70 and ubiquitin mRNA levels in Tetrahymena cells treated with the microtubule depolymerizing/polymerizing agents colchicine and taxol, respectively. (A) Total cytoplasmic RNA $(30 \mu \mathrm{g})$ from exponentially growing cells, from colchicine $(10 \mathrm{mM})$ treated cells for $15 \mathrm{~min}, 30 \mathrm{~min}, 60$ min and $90 \mathrm{~min}$ and from taxol $(50 \mu \mathrm{M})$ treated cells for $15 \mathrm{~min}, 30$ $\mathrm{min}, 60 \mathrm{~min}$ and $90 \mathrm{~min}$ was analyzed in $1.5 \%(\mathrm{w} / \mathrm{v})$ agarose formaldehyde gels, transferred to nitrocellulose filters, and hybridized with the following probes: $\beta$-tubulin - a $3 \mathrm{~kb}$ HindIII fragment from IB1 plasmid containing the $\beta$-tubulin gene ( $\beta T T 1)$ [30]; TpCCT $\alpha-\sim 2.9 \mathrm{~kb}$ EcoRI fragment from TpCCT $\alpha 1.1[23] ; T p C C T \varepsilon-\sim 4.3 \mathrm{~kb} S p h \mathrm{I}$ fragment from TpCCTع6.1.1; TpCCT $\gamma-\sim 2.2 \mathrm{~kb} E c o \mathrm{RI}$ fragment from pTpE3 plasmid [21]; TpCCT $\eta \sim 2.3 \mathrm{~kb}$ HindIII fragment from ТрССТท11.3 [22]; actin - a specific oligomer probe (see Section 2); hsp70 - a specific oligomer probe [26]; ubiquitin - $0.23 \mathrm{~kb}$ HindIII fragment from pTU20 plasmid [33]. The results shown are representative of three to five independent experiments that gave similar results. The autoradiograms have been digitally generated and processed as described in Section 2.
90 min of drug treatment tubulin mRNAs already reached levels similar to those found in exponentially growing cells whereas the $T p C C T$ subunit mRNAs reached levels higher than those of control cells. When cells were treated with taxol at different times, as shown in Fig. 4, we observed that in the first $30 \mathrm{~min}$ of treatment the $T p C C T \alpha$, $T p C C T \varepsilon, T p C C T \gamma$ and $T p C C T \eta$ subunit genes exhibit a different pattern of expression compared to that of $\beta$-tubulin genes ( $\beta T T 1)$. Indeed, we found a decrease in TpCCT subunit mRNA levels between 15 and $30 \mathrm{~min}$ of taxol treatment whereas the amount of tubulin mRNAs is progressively increasing up to levels higher than that found in control cells, until $90 \mathrm{~min}$ of taxol treatment (Fig. 4). However, after the initial $30 \mathrm{~min}$ of taxol treatment the steady-state populations of TpCCT subunit mRNAs also increased to values much higher than those found in exponentially growing cells (see Fig. 4). Interestingly, the expression of actin, the other major substrate of the cytosolic chaperonin, is not significantly affected by treatment with taxol or colchicine (Fig. 4).

It is plausible to assume that dramatic modifications in Mt dynamics caused by colchicine and taxol could be a stress event for Tetrahymena cells. In this perspective we have studied the expression of hsp70 and ubiquitin genes in cells treated with the referred antimitotic agents. Fig. 4 shows that a transcript of about $2.4 \mathrm{~kb}$, corresponding to hsp70, is expressed at barely detectable levels in exponentially growing cells, that it slightly increases after $30 \mathrm{~min}$ of treatment with colchicine and is maintained until $90 \mathrm{~min}$ of treatment. In taxol treated cells a similar type of induction of hsp70 mRNAs occurred but only after $60 \mathrm{~min}$ of treatment. Comparison of these results with those obtained for Tetrahymena cells submitted to a hyperthermic shock or recovering their cilia [26] shows that up-regulation of hsp70 by taxol and colchicine follows a different pattern. In fact, the hsp70 gene is strongly induced immediately after $15 \mathrm{~min}$ of heat shock or cilia recovery and rapidly decreases to the levels of control cells at $30 \mathrm{~min}$. Ubiquitin genes are actively induced by heat shock [37], and we observed an increase in the $1.8 \mathrm{~kb}$ mRNA species after 15 min of treatment with colchicine or taxol (see Fig. 4). This induction is more visible for colchicine treated cells. A slight induction of the $1.6 \mathrm{~kb}$ mRNA is also detected between 15 and $60 \mathrm{~min}$ of colchicine treatment. Noteworthy is the appearance of a $1.4 \mathrm{~kb}$ mRNA species in cells treated with colchicine and taxol for 15 and 30 min. This mRNA species was never described as being specifically induced under stress conditions in $T$. pyriformis cells. On the other hand, the $0.75 \mathrm{~kb}$ ubiquitin fusion gene transcripts coding for 53 amino acid extension protein [33] remained almost unaltered during the treatment with the referred antimitotic agents. The effects on the induction of hsp70 and ubiquitin genes by colchicine and taxol are not comparable both with respect to time and to the extent of the expression induced by heat shock. However, our results unequivocally show that these genes are 
induced, indicating that the dramatic damage in Mt arrays caused by these drugs (see Fig. 3) originates a specific stress event in Tetrahymena cells.

\subsection{CCT, tubulin and ubiquitin gene transcription in Tetrahymena cells treated with the polymerizing and depolymerizing agents taxol and colchicine}

To understand the mechanisms underlying the regulation of $T p C C T \alpha, T p C C T \varepsilon, T p C C T \gamma, T p C C T \eta$, tubulin and ubiquitin gene expression after treatment with the antimitotic agents we investigated the apparent rate of transcription of these genes by run-on transcription assays in nuclei isolated from cells treated with taxol and colchicine for 15 and $60 \mathrm{~min}$ (Fig. 5). The results show that the apparent rate of transcription of tubulin and TpCCT subunit genes is higher in nuclei isolated from cells exposed to taxol than in nuclei isolated from exponentially growing cells (Fig. 5A). In fact, the apparent rate of transcription of tubulin and TpCCT subunit genes is increased after 15 min of taxol treatment and continues to increase until 60 $\min$.

The apparent rate of transcription of $\alpha$-tubulin, TpCCTE and TpCCT $\eta$ genes is maintained almost constant until $15 \mathrm{~min}$ of colchicine treatment, reaching values higher than those found in nuclei isolated from control cells at $60 \mathrm{~min}$ (Fig. 5B). In contrast, nuclei isolated from cells treated with colchicine for $15 \mathrm{~min}$ are already more active in producing $\beta$-tubulin, TpCCT $\gamma$ and ubiquitin transcripts than nuclei isolated from exponentially growing cells. Nevertheless, the highest levels of the apparent rate of transcription of these genes is also observed in nuclei obtained from cells submitted to colchicine for 60 min. Interesting is the fact that $T p C C T \alpha$ presents a different pattern of induction compared to the other genes analyzed. Indeed, the transcripts of TpCCT $\alpha$ show an increase in nuclei of cells treated with colchicine for 15 min followed by a decrease to the levels found in nuclei isolated from control cells.

The taxol and colchicine results taken together show that the decrease detected in the steady-state populations of tubulin and TpCCT subunit mRNAs between 15 and 30 min of colchicine treatment and the slight decrease of TpCCT subunit mRNAs between 15 and 30 min of exposure to taxol cannot be due to down-regulation of the transcription rate of these genes. These results suggest that the decrease in the amounts of TpCCT subunit mRNAs might be the result of posttranscriptional events. In fact, this is consistent with our data on studies of TpCCT $\eta$ mRNA stability that show that the half-life of this mRNA decreases in cells treated with colchicine and taxol compared to that of control cells (results not shown). Moreover, the up-regulation of the studied genes correlates with the increased levels of tubulin and TpCCT subunit mRNAs found in cytoplasm between 60 and $90 \mathrm{~min}$ of colchicine and taxol treatment. In the case of ubiquitin genes, the increased apparent rate of transcription in nuclei isolated from cells subject to colchicine supports the induction of the $1.8 \mathrm{~kb}$ mRNA species and the synthesis de novo of the $1.6 \mathrm{~kb}$ and $1.4 \mathrm{~kb}$ mRNA species in the cytoplasm between 15 and $90 \mathrm{~min}$ of exposure to the $\mathrm{Mt}$ depolymerizing agent. The transcription rate of the ubiquitin genes in nuclei isolated from cells treated with taxol for 15 min depicts a slight increase compared to that observed in nuclei isolated from cells treated with colchicine. This explains the fact that in taxol treated cells the in-
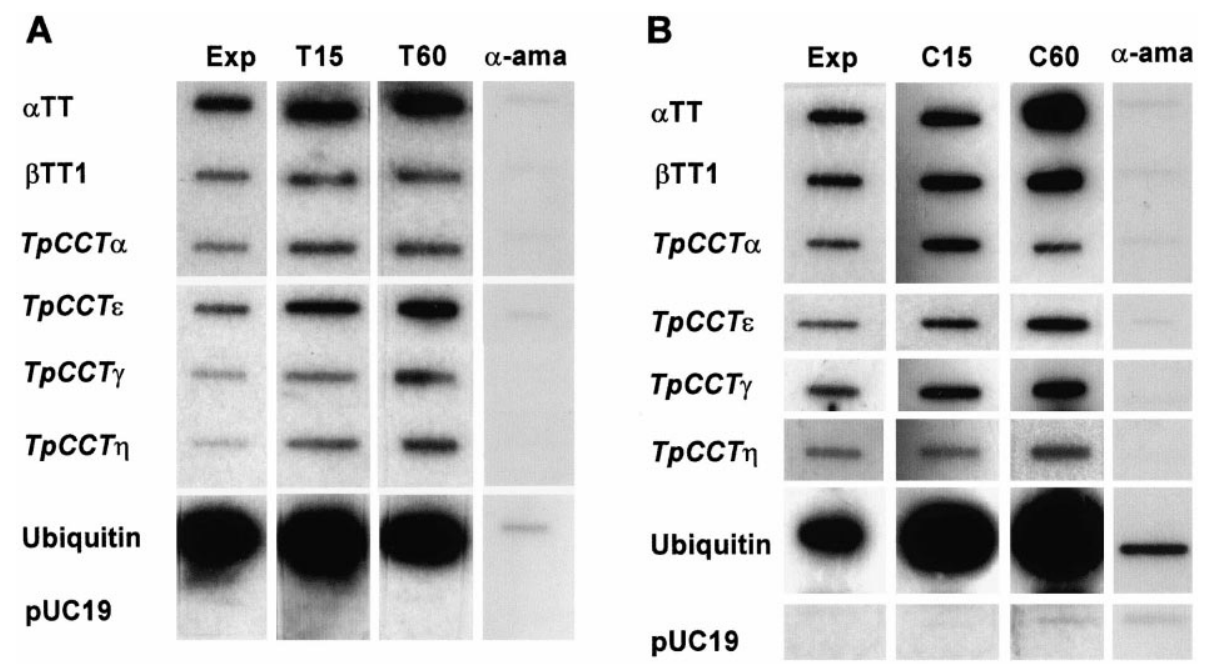

Fig. 5. Tubulin ( $\alpha T T$ and $\beta T T 1$ ), TpCCT $\alpha, T p C C T \varepsilon, T p C C T \gamma, T p C C T \eta$, and ubiquitin transcription in Tetrahymena cells after 15 and 60 min of treatment with taxol and colchicine. Apparent transcription rates were measured by run-on assay. For each sample an equal number of nuclei (about $\left.5 \times 10^{8}\right)$ was used. Nuclei were isolated from exponentially growing cells (Exp), exponentially growing cells incubated with $\alpha$-amanitin $(20 \mu \mathrm{g} / \mathrm{ml})$ for 30 min $(\alpha-a m a)$ and cells treated with taxol (A) and colchicine (B) for 15 and 60 min (T15, T60 and C15, C60, respectively). Nuclear RNA was extracted and hybridized to DNA previously bound to nitrocellulose filters. Each slot contained $1 \mu \mathrm{g}$ of DNA fragments containing the $T p C C T \alpha, T p C C T \varepsilon$, $T p C C T \gamma, T p C C T \eta, \alpha$ - and $\beta$-tubulin ( $\alpha T T$ and $\beta T T 1$, respectively) and ubiquitin genes. The data are representative of three different experiments on separate isolations of nuclei that gave identical results. The autoradiograms have been digitally generated and processed as described in Section 2 . 
crease in the amount of steady-state population of ubiquitin mRNAs is smaller than in colchicine treated cells and is essential owing to the increase of the $1.8 \mathrm{~kb}$ mRNA species.

\subsection{The steady-state protein levels of CCT subunits and tubulin in cells treated with taxol and colchicine}

The effects of taxol and colchicine on transcription led us to assay the steady-state amounts of proteins of different CCT subunits and tubulin in Tetrahymena. We have analyzed total and postmitochondrial extracts of Tetrahymena exponentially growing cells and cells treated with taxol or colchicine for 15 and $90 \mathrm{~min}$ by $10 \%$ SDSPAGE followed by immunoblotting with the set of antibodies produced against distinct CCT subunits and tubulin (see Section 2 and Fig. 2). Interestingly, although all CCT subunit genes studied showed similar patterns of expression in taxol and colchicine treated cells (see Fig. 4) we observed varying changes in the steady-state levels of the respective proteins in the distinct protein fractions. Analysis of total protein extracts shows that the levels of CCT $\alpha$, CCT $\varepsilon$ and CCT $\eta$ subunits and tubulin did not change significantly during taxol treatment $\left(\right.$ Fig. $\left.6 \mathrm{I}_{\mathrm{A}}\right)$. In postmitochondrial extracts the amounts of CCT $\alpha$ and CCT $\eta$ subunits are maintained almost constant in cells treated with taxol. However, in the soluble fraction of these cells there is a dramatic decrease in the levels of CCTE subunit (Fig. 6 $\mathrm{I}_{\mathrm{B}}$ ), while the levels of the CCT substrate, tubulin, almost disappear in cells treated with taxol for $15 \mathrm{~min}$ and subsequently increase to levels almost comparable to that of the control cells at 90 min of treatment (Fig. $6 \mathrm{I}_{\mathrm{B}}$ ). In order to explain this apparent discrepancy between gene expression and the steady-state amounts of the CCT subunits and tubulin under taxol treatment, we decided to analyze by Western blot the corresponding pellets obtained during the preparation of the postmitochondrial extracts. Unexpectedly, we observed that CCT $\alpha$ as well as the CCTE subunit were detectable in the insoluble fraction of exponentially growing cells while CCT $\eta$ was vestigial (Fig. $6 \mathrm{I}_{\mathrm{C}}$ ). Moreover, the levels of $\mathrm{CCT} \varepsilon$ were more abundant in insoluble fractions than in soluble fractions in contrast with the other CCT subunits $\left(\right.$ Fig. $6 \mathrm{I}_{\mathrm{C}}$ ). The levels of this subunit clearly increase in the insoluble fraction in cells treated with taxol at the expense of a corresponding decrease in the soluble fraction. CCT $\alpha$ subunit levels in the insoluble fraction are apparently unchanged during taxol treatment. Tubulin was expected to be detected in insoluble fractions in exponentially growing cells since Tetrahymena is a ciliate and insoluble fractions contain all the cilia and probably part of the cortex structure. After $15 \mathrm{~min}$ of taxol treatment tubulin is only present in the insoluble fraction, probably due to massive polymerization, and can only be detected in the soluble fraction after $90 \mathrm{~min}$ of taxol treatment (see Fig. $6 \mathrm{I}_{\mathrm{B}}$ ). This last observation can be explained by the up-regula- tion of tubulin genes and de novo protein synthesis as a compensation response to taxol challenge.

Fig. 6II shows the results obtained with colchicine treated cells when performing experiments similar to those above described for taxol. We observed that in total protein extracts the amounts of CCT $\alpha$ and CCT $\eta$ subunits and tubulin slightly decrease whereas the levels of CCTE show a small increase. Interestingly, the levels of all these proteins progressively decrease until $90 \mathrm{~min}$ of treatment in the soluble fraction (Fig. $6 \mathrm{II}_{\mathrm{B}}$ ). In the insoluble fraction the amounts of CCTE increase whereas the amounts $\mathrm{CCT} \alpha$ remain almost constant and tubulin levels are declining (Fig. $6 \mathrm{II}_{\mathrm{C}}$ ). As in taxol treated cells CCT $\eta$ is almost undetectable in the insoluble fraction both in control cells and in cells subjected to colchicine (Fig. $\left.6 \mathrm{II}_{\mathrm{C}}\right)$. Therefore, the depolymerization of $\mathrm{Mt}$ arrays by colchicine promotes the decrease of the steady-state populations of CCT subunits and tubulin in soluble fractions. In the case of CCTE subunit this decrease seems to be explained by the shift of this protein from soluble fraction to insoluble fraction. Since CCT $\alpha$ and CCT $\eta$ subunit genes and tubulin genes are up-regulated in cells treated with colchicine, we hypothesized that the observed decrease in the soluble protein levels was due to an accelerated proteolytic degradation of these proteins. To test this hypothesis we performed experiments where colchicine was added to Tetrahymena cultures $15 \mathrm{~min}$ after the addition of cycloheximide, an elongation inhibitor of translation. These experiments showed that the half-life of these proteins was not affected by colchicine and it was longer than 90 min (results not shown). A possible explanation for these apparent incongruent observations can be the fact that the factor involved in the degradation of these proteins in cells treated with colchicine is absent due to the blockage of protein synthesis. This idea is reinforced by the fact that the decrease of tubulin in cells treated with colchicine with inhibited protein synthesis is no longer observed at $90 \mathrm{~min}$ (results not shown).

The presence of CCT subunits in the insoluble fraction either in exponentially growing cells or in cells treated with taxol and colchicine raises the possibility of contamination from the soluble fraction. We think that this is not the case for two reasons: (i) during preparation of insoluble fractions, pellets were extensively washed in order to avoid contamination; (ii) it is difficult to explain the presence of distinct CCT subunits in these fractions (note that CCT $\eta$ is practically absent) and also their varying amounts with the physiological state of the cell. By assuming that specific CCT subunits either free or as part of small oligomeric structures can be associated with Mt arrays [18] the presence of CCT subunits in insoluble fractions treated with Mt polymerizing agent could be explained. Detection of CCTE and CCT $\alpha$ subunits in the insoluble fraction could be due to a preferential association of these subunits with Mts that are massively polymerized by taxol. However, this idea is not supported by the studies involving 


\section{I}

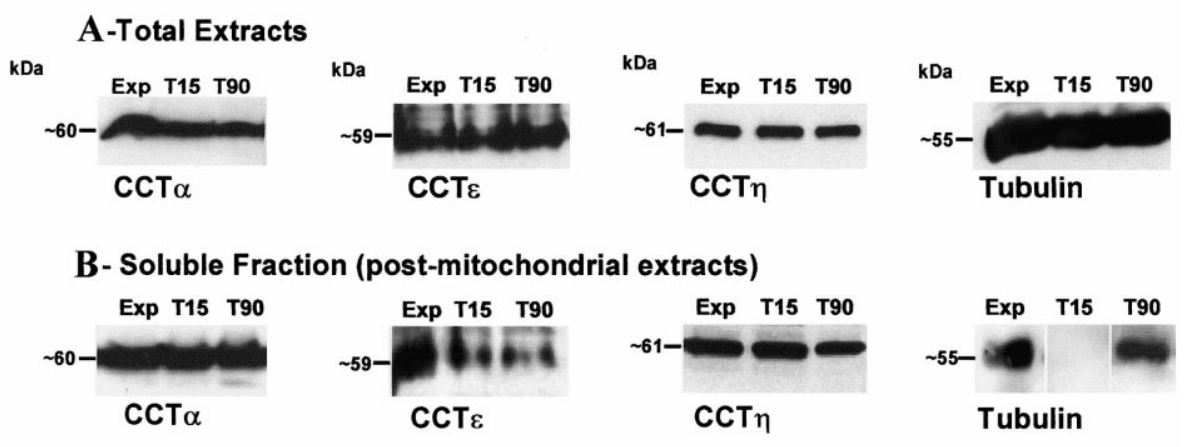

\section{C-Insoluble Fraction (pellet)}

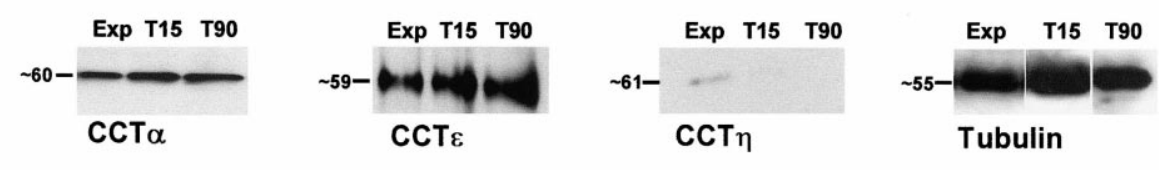

II

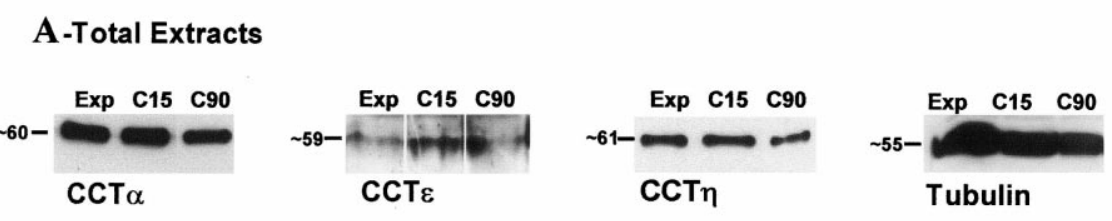

\section{B-Soluble Fraction (post-mitochondrial extracts)}

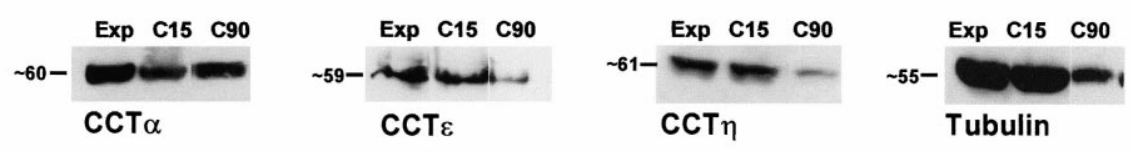

\section{C-Insoluble Fraction (pellet)}
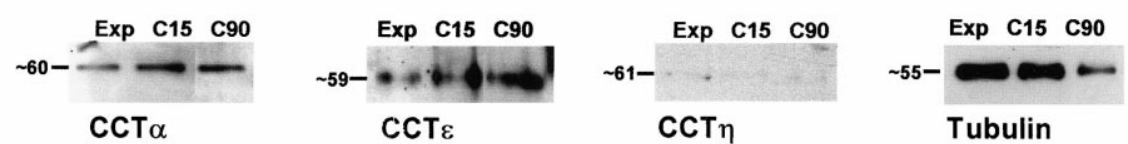

Fig. 6. Analysis of the steady-state levels of Tetrahymena CCT subunits and tubulin of the exponentially growing cells and cells treated with taxol and colchicine. Protein extracts obtained from exponentially growing cells (control) (Exp) and cells subjected to taxol (I) and colchicine (II) for 15 min (T15 and $\mathrm{C} 15$, respectively) and $90 \mathrm{~min}$ (T90 and C90, respectively) were analyzed by $10 \%$ (w/v) SDS-polyacrylamide gradient gels and then Western blotted. $\left(\mathrm{I}_{\mathrm{A}}, \mathrm{II}_{\mathrm{A}}\right)$ Total protein extracts; $\left(\mathrm{I}_{\mathrm{B}}, \mathrm{II}_{\mathrm{B}}\right)$ postmitochondrial extracts (soluble fraction); ( $\left.\mathrm{I}_{\mathrm{C}}, \mathrm{II}_{\mathrm{C}}\right)$ the respective pellets (corresponding to the insoluble frac-

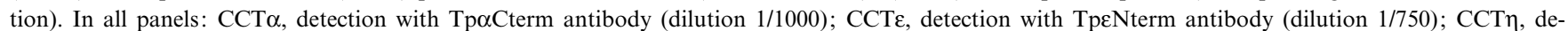
tection with Tp $\eta$ Cterm antibody (dilution 1/1000); tubulin, detection with monoclonal antibody against to $\alpha$-tubulin N356 (see Section 2). The secondary antibody was always used at 1/1000 dilution except in the case of TpeNterm antibody where a 1/750 dilution was used. The approximate molecular mass of the identified proteins is always indicated at the left. The results shown are representative of three independent experiments that gave similar results. The autoradiograms have been digitally generated and processed as described in Section 2.

colchicine. In fact, this Mt depolymerizing agent also induces the preferentially transition of CCTE from the soluble to the insoluble fraction and CCT $\alpha$ subunit is still detected in the insoluble fraction in cells treated with this agent. Alternatively, the presence of CCT $\alpha$ and CCTE in the insoluble fractions could be due to an association of these subunits with components of cortex structure and/or with basal bodies and/or cilia. If this is true, it is possible that there is a preferential association of the
ССТ $\varepsilon$ subunit with these structures when dramatic alterations on Mt structures occur due to accentuated polymerization or depolymerization.

\section{Discussion}

We have previously shown that four members of the CCT subunit family genes of Tetrahymena [21-24] are 
conserved from protozoan to metazoan [1]. The present work reports the identification and characterization of the fifth member of this family, ТрCCT $\varepsilon$. Comparison of the predicted amino acid sequence of TpCCTE with the other known CCTE subunits from other organisms revealed that besides the usual characteristic motifs of almost all the chaperonins of group I [1] and members of the CCT/TF55 proteins, it contains five new, highly conserved regions that seem to be exclusively shared by CCTE subunits (see Fig. 1). It is likely that these sequences could be involved in a specific function of the CCT $\varepsilon$ subunit in the chaperonin complex. In fact, it has recently been shown that the small domain of $\alpha$-actin interacts with СCT $\delta$ and that the large domain interacts with ССТ $\beta$ or CCTE, indicating that the binding of this substrate to CCTs is subunit-specific [2,38]. Moreover, tubulin interacts with CCT using five specific CCT subunits with the strong interactions being through either ССТع or ССТ $\beta$ [39].

This study focuses on the effects of taxol and colchicine on Mt arrays and on the regulation of the expression of CCT subunit genes. Our data show that taxol induced polymerization and bundling of Tetrahymena Mt arrays preferentially localized around the macronucleus (Fig. 3), whereas colchicine clearly induces the depolymerization of cytoplasmic Mt networks and also affects the cortex Mts. Colchicine provokes a similar pattern of expression of tubulin and CCT subunit genes and does not affects actin expression. On the other hand, taxol induces tubulin but not actin transcripts to progressively increase to levels much higher than those found in control cells. Interestingly, at the same time the mRNA levels of the CCT subunit genes decrease in cytoplasm between 15 and $30 \mathrm{~min}$ and then rise to levels higher than those found in untreated cells. The apparent rate of transcription of the tubulin and CCT subunit genes is up-regulated in cells treated with colchicine and taxol. However, the pattern of induction is not exactly the same in both cases (see Fig. 5). The results taken together suggest a different type of regulation mechanism of CCT subunit gene expression between cells treated with Mt polymerizing and Mt depolymerizing agents. Besides this, it is relevant to note that CCT subunit gene expression is modified by perturbations in Mts arrays caused either by dramatic depolymerization or polymerization, suggesting a complex mechanism of regulation between these genes and Mt cytoskeleton status.

The transcription studies also show that the decrease of CCT mRNA levels in cytoplasm between 15 and $30 \mathrm{~min}$ in cells subjected either to taxol or colchicine, and the decrease of tubulin mRNA amounts in cells treated with colchicine cannot be transcriptional and may be a result of a posttranscriptional regulation at the level of mRNA stability. Both antimitotic drugs increase transcription of $\alpha$ - and $\beta$-tubulin presumably to replenish the cytoplasmic soluble pool of functional tubulin [27]. The up-regulation of CCT subunit genes has been linked to the increased synthesis of tubulin, $[4,21,22,40]$ and is probably required to chaperone the folding of the newly synthesized tubulin pool. However, the increase of transcription of CCTs does not correlate with a corresponding increase in the steadystate levels of these proteins (see Fig. 6). Therefore, the upregulation of CCT genes is probably required to replete the physiological levels of the CCT mRNA in cytoplasm since, as explained earlier, taxol and colchicine induce CCT mRNA degradation in cytoplasm. Although the regulatory mechanisms of CCT subunits and tubulin mRNAs stability are different and largely unknown, it is tempting to suggest that they could be related with the integrity and dynamics of Mt cytoskeleton. Several lines of evidence indicate that cytoskeleton is important for translation since translational components including ribosomes and initiation factors are physically associated with it [41,42]. In many instances translation has a direct role in determining mRNA stability as mRNA degradation may be coupled with translation [26,42].

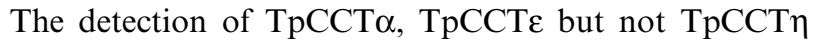
in the insoluble protein fraction in exponentially growing cells is a striking observation (see Fig. 6B). These results are consistent with the idea that some CCT subunits exist as free subunits or as part of oligomeric particles associated with Mt arrays and/or with MTOCs (microtubuleorganizing centers). Indeed $\mathrm{CCT} \alpha$, as well as $\mathrm{CCT} \zeta$, have been described as part of mammalian centrosomes $[18,19]$. Recently, Roobol et al. [19] have shown that $\mathrm{CCT} \alpha, \gamma, \zeta$ and $\theta$ but not $\mathrm{CCT} \varepsilon$ were able to associate with Mt polymerized in vitro by taxol. CCT $\alpha$ subunit was detected in sea urchin embryonic and rabbit tracheal cilia [43] and progressively appeared in regenerating embryonic cilia as their growth slowed down, suggesting a regulatory role correlated with growth or turnover. In our in vivo experiments $\mathrm{CCT} \alpha$ and $\mathrm{CCT} \varepsilon$ subunits appear in the insoluble fraction that contains parts of the cortex structure, including basal bodies and cilia, indicating a putative association of these subunits with the mentioned Mt structures. Unexpectedly, the CCTE association is stimulated by either taxol or colchicine, suggesting that it is not a simple consequence of association with Mts due to a massive polymerization. Instead this association may be related with the damage of Mt organization/dynamics in the Mt containing structures present in the insoluble fraction. Our data contribute to strengthen the hypothesis that CCT subunits free or as part of oligomeric complexes could have distinct additional roles in vivo since they are differentially detected associated with structures where protein synthesis is not supposed to occur and consequently protein folding is not expected. Studies are in progress in order to identify whether TpCCTE binds to the microtubule structures or some other non-soluble organelle(s) present in the insoluble fraction. 


\section{Acknowledgements}

We are deeply grateful to Dr. Carmo-Fonseca and Dr. João Ferreira (Univ. Lisboa) for providing confocal microscopy facilities and helpful advice given during immunofluorescence studies. This work was supported by funds from PRAXIS/PCNA/BIO/67/96. C.C. received a fellowship from PRAXIS/BD/9208/96.

\section{References}

[1] H. Kubota, G. Hynes, K. Willison, The chaperonin containing t-complex-polypeptide 1 (TCP-1), Eur. J. Biochem. 230 (1995) 3-16.

[2] O. Llorca, E.A. McCormack, G. Hynes, J. Grantham, J. Cordell, J.L. Carrascosa, K.R. Willison, J.J. Fernandez, J.M. Valpuesta, Eukaryotic type II chaperonin CCT interacts with actin through specific subunits, Nature 402 (1999) 693-696.

[3] P. Lin, F. Sherman, The unique hetero-oligomeric nature of the subunits in the catalytic cooperativity of the yeast CCT chaperonin complex, Proc. Natl. Acad. Sci. USA 94 (1997) 10780-10785.

[4] K.R. Willison, G. Hynes, P. Davies, A. Goldsborough, V.A. Lewis, Expression of three t-complex genes, Tcp-1, D17Leh117c3 and D17Leh66, in purified murine spermatogenic cell populations, Genet. Res. 56 (1990) 193-201.

[5] H. Kubota, K. Willison, A. Ashworth, M. Nozaki, H. Miyamoto, A. Yammamoto, A. Matsushiro, T. Morita, Structure and expression of the gene encoding t-complex-polypeptide 1 (Tcp-1), Gene 120 (1992) $207-215$.

[6] S. Yokota, H. Yanagi, T. Yura, H. Kubota, Cytosolic chaperonin is up-regulated during cell growth, J. Biol. Chem. 274 (1999) 3707037078 .

[7] S. Yokota, H. Yanagi, T. Yura, H. Kubota, Upregulation of cytosolic chaperonin CCT subunits during recovery from chemical stress that causes accumulation of unfolded proteins, Eur. J. Biochem. 267 (2000) 658-1664.

[8] D. Miklos, S. Caplan, S. Mertens, G. Hynes, Z. Pitluk, Y. Kashi, K. Harrison-Lavoie, S. Stevenson, C. Brown, B. Barrel, A.L. Horwich, K. Willison, Primary structure and function of a second essential member of the heterooligomeric TCP1 chaperonin complex of yeast, TCP1ß, Proc. Natl. Acad. Sci. USA 91 (1994) 2743-2747.

[9] X. Chen, D.S. Sullivan, T.C. Huffaker, Two yeast genes with similarity to TCP-1 are required for microtubule and actin function in vivo, Proc. Natl. Acad. Sci. USA 91 (1994) 9111-9115.

[10] D.B.-N. Vinh, D.G. Drubin, A yeast TCP-1-like protein is required for actin function in vivo, Proc. Natl. Acad. Sci. USA 91 (1994) 9116-9120.

[11] Y. Gao, R. Melki, P.D. Walden, S.A. Lewis, C. Ampe, H. Rommelaere, J. Vandekerckove, N.J. Cowan, A novel cochaperonin that modulates the ATPase activity of cytoplasmic chaperonin, J. Cell Biol. 125 (1994) 989-995.

[12] G. Tian, S.A. Lewis, B. Feierbach, T. Stearns, H. Rommelaere, C. Ampe, N.J. Cowan, Tubulin subunits exist in an activated conformational state generated and maintained by protein cofactors, J. Cell Biol. 138 (1997) 821-832.

[13] G. Tian, A. Bhamidipati, N.J. Cowan, S.A. Lewis, Tubulin folding cofactors as GTPase-activating proteins, J. Biol. Chem. 274 (1999) $24054-24058$.

[14] A. Liou, K. Willison, Elucidation of the subunit orientation in CCT (chaperonin containing TCP1) from the subunit composition of CCT micro-complexes, EMBO J. 16 (1997) 4311-4316.

[15] A. Roobol, M.J. Carden, Subunits of the eukaryotic cytosolic chaperonin CCT do not always behave as components of a uniform hetero-oligomeric particle, Eur. J. Cell Biol. 78 (1999) 21-32.
[16] H. Soares, L. Cyrne, C. Casalou, A.M. Coutinho, M. Rebelo, C. Rodrigues-Pousada, A set of CCT-micro-complexes are present in Tetrahymena cells: studies during cilia recovery and treatment with microtubule polymerising depolymerising agents, in: Abstracts of the 14th Meeting of the European Cytoskeleton Forum, Euroconference no. ERBFMMACT98044 published by the organizing committee, 1999.

[17] C. Casalou, L. Cyrne, A.M. Coutinho, M. Rebelo, C. RodriguesPousada, H. Soares, Are the CCT micro-complexes intermediates of assembly of the $900 \mathrm{kDa}$ complex in Tetrahymena cells? in: Abstracts of the 14th Meeting of the European Cytoskeleton Forum, Euroconference no. ERBFMMACT98044 published by the organizing committee, 1999.

[18] C.R. Brown, L.Q. Hong-Brown, S.J. Doxsey, W.J. Welch, Molecular chaperones and the centrosome, J. Biol. Chem. 271 (1996) 833-840.

[19] A. Roobol, Z.P. Sahyoun, M.J. Carden, Selected subunits of the cytosolic chaperonin associate with microtubules assembled in vitro, J. Biol. Chem. 274 (1999) 2408-2415.

[20] F. Rademacher, V. Kehren, V.R. Stoldt, J.F. Ernst, A Candida albicans chaperonin subunit (CaCct8p) as a suppressor of morphogenesis and Ras phenotypes in C. albicans and Saccharomyces cerevisiae, Microbiology 144 (1998) 2951-2960.

[21] H. Soares, D. Penque, C. Mouta, C. Rodrigues-Pousada, A Tetrahymena orthologue of the mouse chaperonin subunit CCT gamma and its coexpression with tubulin during cilia recovery, J. Biol. Chem. 269 (1994) 29299-29307.

[22] L. Cyrne, P. Guerreiro, A.C. Cardoso, C. Rodrigues-Pousada, H. Soares, The Tetrahymena chaperonin subunit CCT $\eta$ gene is coexpressed with CCT gene during cilia biogenesis and sexual reproduction, FEBS Lett. 383 (1996) 277-283.

[23] H. Soares, L. Cyrne, C. Casalou, B. Ehmann, C. Rodrigues-Pousada, The third member of the Tetrahymena CCT subunit gene family, $\mathrm{TpCCT} \alpha$ encodes a component of the hetero-oligomeric chaperonin complex, Biochem. J. 326 (1997) 21-29.

[24] C. Domingues, H. Soares, C. Rodrigues-Pousada, L. Cyrne, Structure of Tetrahymena CCT $\theta$ gene and its expression under colchicine treatment, Biochim. Biophys. Acta 1446 (1999) 443-449.

[25] C. Rodrigues-Pousada, M.L. Cyrne, D. Hayes, Characterization of preribosomal ribonucleoprotein particles from Tetrahymena pyriformis, Eur. J. Biochem. 56 (1979) 117-122.

[26] H. Soares, L. Galego, R. Cóias, C. Rodrigues-Pousada, The mechanisms of tubulin messenger regulation during Tetrahymena pyriformis reciliation, J. Biol. Chem. 268 (1993) 16623-16630.

[27] L.A. Stargell, D.P. Heruth, J. Gaerting, M.A. Gorovsky, Drugs affecting microtubule dynamics increase $\alpha$-tubulin mRNA accumulation via transcription in Tetrahymena thermophila, Mol. Cell. Biol. 12 (1992) 1443-1450.

[28] H. Kubota, G. Hynes, A. Carne, A. Ashworth, K. Willison, Identification of six Tcp-1-related genes encoding divergent subunits of the TCP-1-containing chaperonin, Curr. Biol. 4 (1994) 89-99.

[29] J. Sambrook, E.F Fritsch, T. Maniatis, Molecular Cloning: a Laboratory Manual, 2nd edn., Cold Spring Harbor Laboratory Press, Cold Spring Harbor, NY, 1989.

[30] I. Barahona, H. Soares, L. Cyrne, D. Penque, P. Denoulet, C. Rodrigues-Pousada, Sequence of one $\alpha$ - and two $\beta$-tubulin genes of Tetrahymena pyriformis. Structural and functional relationships with other eukaryotic tubulin genes, J. Mol. Biol. 202 (1988) 365382.

[31] M. Hirono, H. Endoh, N. Okada, O. Numata, Y. Watanabe, Tetrahymena actin. Cloning and sequencing of the Tetrahymena actin gene and identification of its gene product, J. Mol. Biol. 194 (1987) 181192.

[32] H. Soares, L. Cyrne, I. Barahona, C. Rodrigues-Pousada, Different patterns of expression of $\beta$-tubulin genes in Tetrahymena pyriformis during reciliation, Eur. J. Biochem. 197 (1991) 291-299.

[33] A.M. Neves, P. Guerreiro, L. Miquerol, C. Rodrigues-Pousada, Molecular cloning and expression of a Tetrahymena pyriformis ubiquitin 
fusion coding for a 53 aa extension protein, Mol. Gen. Genet. 230 (1991) 186-192.

[34] T. Carvalho, F. Almeida, A. Calapez, M. Lafarga, M.T. Berciano, M. Carmo-Fonseca, The spinal muscular atrophy disease gene product, SMN: a link between snRNP biogenesis and the Cajal (coiled) body, J. Cell Biol. 147 (1999) 715-728.

[35] W. Spencer, H. Kwon, P. Crépieux, N. Leclerc, R. Lin, J. Hiscott, Taxol selectively blocks microtubule dependent NF-kappaB activation by phorbol ester via inhibition of IkappaBalpha phosphorylation and degradation, Oncogene 18 (1999) 495-505.

[36] P.J. Moos, D.T. Muskardin, F.A. Fitzpatrick, Effect of taxol and taxotere on gene expression in macrophages: induction of the prostaglandin h synthase-2 isoenzyme, J. Immunol. 162 (1999) 467-473.

[37] A.M. Neves, I. Barahona, L. Galego, C. Rodrigues-Pousada, Ubiquitin genes in Tetrahymena pyriformis and their expression during heat shock, Gene 73 (1988) 87-96.

[38] G. Hynes, K.R. Willison, Individual subunits of the eukaryotic cytosolic chaperonin mediate interactions with binding sites located on subdomains of $\beta$-actin, J. Biol. Chem. 275 (2000) 18985-18994.
[39] O. Llorca, J. Martin-Benito, M. Ritco-Vonsovici, J. Grantham, G.M. Hynes, K.R. Willison, J.L. Carrascosa, J.M. Valpuesta, Eukaryotic chaperonin CCT stabilizes actin and tubulin folding intermediates in open quasi-native conformations, EMBO J. 19 (2000) 59715979.

[40] A. Roobol, F.E. Holmes, N.V.L. Hayes, A.J. Baines, A.J. Carden, Cytoplasmic chaperonin complex enter neurites developing in vitro and differ in subunit composition within single cells, J. Cell Sci. 108 (1995) 1477-1488.

[41] R.-P. Jansen, RNA cytoskeletal associations, FASEB J. 13 (1999) 455-466.

[42] N.G. Theodorakis, D.W. Cleveland, in: Translational Control: Translationally Coupled Degradation of mRNA in Eukaryotes, 1st edn., Cold Spring Harbor Laboratory Press, Cold Spring Harbor, NY, 1996 pp. 631-652.

[43] R.E. Stephens, N.A. Lemieux, Molecular chaperones in cilia and flagella: implications for protein turnover, Cell Motil. Cytoskeleton 44 (1999) 274-283. 